\title{
PENGARUH JENIS PUPUK KANDANG DAN UKURAN PEMOTONGAN UJUNG UMBI TERHADAP PERTUMBUHAN DAN PRODUKSI TANAMAN BAWANG MERAH (Allium ascalonicum L.)
}

\author{
Adnan $^{1}$, Boy Riza Juanda ${ }^{1}$, Muhammad Rian Nugraha ${ }^{2}$ \\ ${ }^{1}$ Dosen Program Studi Agroteknologi, Fakultas Pertanian Universitas Samudra \\ ${ }^{2}$ Alumni Program Studi Agroteknologi, Fakultas Pertanian Universitas Samudra \\ e-mail: adnan@unsam.ac.id
}

\begin{abstract}
ABSTRAK
Penelitian ini bertujuan untuk mengetahui pengaruh jenis pupuk kandang dan ukuran pemotongan ujung umbi terhadap pertumbuhan dan produksi tanaman bawang merah (Allium ascalonicum L). Penelitian ini menggunakan RAK pola faktorial yang terdiri dari dua faktor: jenis pupuk kandang dengan notasi $(\mathrm{k})$ yang terdiri dari 4 taraf adalah $\mathrm{k} 0$ : kontrol, $\mathrm{k} 1$ : pupuk kandang ayam 2,5 kg/plot, k2 : pupuk kandang kambing 2,5 kg/plot dan $\mathrm{k} 3$ : pupuk kandang bebek 2,5 kg/plot. Sedangkan ukuran pemotongan ujung umbi dengan notasi $(\mathrm{p})$ yang terdiri dari 3 taraf yaitu : p0 : tanpa pemotongan, $\mathrm{p} 1$ : pemotongan $1 / 4$ bagian, $\mathrm{p} 2:$ pemotongan $1 / 3$ bagian. Pengamatan dilakukan terhadap tiggi tanaman umur 15,30 dan 45 HST, jumlah daun umur 15, 30 dan 45 HST, jumlah umbi pertanaman sampel, berat segar umbi tanaman per sampel, berat segar umbi per plot, berat kering umbi tanaman per sampel dan berat kering umbi tanaman per plot. Hasil Pemberian jenis pupuk kandang berpengaruh sangat nyata terhadap berat segar umbi per sampel, berat segar umbi per plot dan berat kering umbi per plot. Berpengaruh nyata terhadap tinggi tanaman (45 HST), jumlah daun (15, 30 dan 45 HST), jumlah umbi pertanaman sampel dan berat kering umbi per sampel. Hasil pemberian ukuran pemotongan ujung umbi terbaik diperoleh pada perlakuan $\mathrm{P}_{1}$ (pemotongan $1 / 4$ bagian). Interaksi antara jenis pupuk kandang dan ukuran pemotongan ujung umbi berpengaruh sangat nyata terhadap tinggi tanaman (45 HST). Sedangkan berpengaruh nyata pada tinggi tanaman (30 HST), jumlah daun (15,30 dan 45 HST) dan jumlah umbi pertanaman sampel. Hasil terbaik diperoleh pada kombinasi perlakuan $\mathrm{K}_{3} \mathrm{P}_{1}$ (pengaruh jenis pupuk kandang bebek dan pemotongan $1 / 4$ bagian).
\end{abstract}

Kata kunci : Jenis Pupuk Kandang dan Ukuran Pemotongan Ujung Umbi

\section{PENDAHULUAN}

\section{Latar Belakang Penelitian}

Berdasarkan deskripsi botaninya, tanaman bawang merah memiliki potensi produktivitas yang berada di atas 10-12 ton/ha, namun di lapangan produksi bawang merah rata-rata jauh lebih rendah dari potensi hasilnya. Salah satu yang mempengaruhi produksi bawang merah tersebut ialah luas panen. Pada tahun 2015 luas panen bawang merah ialah $741 \mathrm{Ha}$, tahun 2016 luas panen bawang merah ialah $776 \mathrm{Ha}$ dengan persentase peningkatan sebesar 4,51 \%. Namun produksi bawang merah di Aceh pada tahun 2015 sebesar 9,08 ton/ha dan pada tahun 2016 sebesar 7,4 ton/ha 
mengalami penurunan persentase sebesar 22,72 \% (Kementan, 2017).

Hal tersebut membuktikan bahwa ketersediaan bawang merah dalam negeri belum mencukupi kebutuhan bawang merah yang tinggi, dengan demikian produktivitas bawang merah perlu ditingkatkan lagi. Menurut hasil proyeksi yang dilakukan tahun 20162020, konsumsi nasional bawang merah diproyeksikan akan meningkat dengan bertambahnya jumlah penduduk dengan rata-rata pertumbuhan 2,03 \% per tahun (Kementan 2016).

Dalam meningkatkan hasil bawang merah perlunya perhatian dari segi pemeliharaan pada saat budidaya bawang merah yaitu pemupukan. Pemupukan secara organik lebih banyak disarankan dikarenakan penggunaan pupuk organik mampu memperbaiki sifat fisik dan kimia tanah serta meningkatkan aktivitas mikroorganisme didalam tanah yang berguna bagi pertumbuhan dan produksi tanaman.

Salah satu contoh pupuk organik tersebut ialah pupuk kandang yang berasal dari kotoran sapi, ayam dan bebek yang telah terdekomposisi sempurna. Kandungan unsur hara yang terkandung di dalam pupuk kandang antara lain nitrogen $0,40 \%$, fosfor $0,20 \%$, kalium $0,10 \%$ dan kadar air 85\% (Pranata, 2010). Hasil penelitian yang dilakukan Syamsuddin, $d k k$., (2016) dosis yang dianjurkan berkisar 20 ton/ha. Kandungan unsur hara yang terkandung dalam pupuk kandang diharapkan mampu meningkatkan pertumbuhan tanaman.

Selain dari segi pemupukan hal yang perlu diperhatikan ialah teknik pengukuran pemotongan ujung umbi ketika akan ditanam. biasanya para petani yang menanam bawang merah pemotongan umbi dilakukan dengan cara memotong bagian ujung umbi bibit dengan berbagai ukuran sesuai besar umbi bibit dan biasanya sepanjang kurang lebih sepertiga bagian umbi. Hasil penelitian yang dilakukan Jumini, $d k k$., (2010) pemotongan umbi bibit terbaik didapati pada umbi bibit yang dipotong $1 / 4$ bagian. Berdasarkan uraian diatas, maka penulis ingin melakukan penelitian mengenai "Pengaruh Beberapa Jenis Pupuk Kandang dan Ukuran Pemotongan Ujung Umbi terhadap Pertumbuhan dan Produksi Tanaman Bawang (Allium ascalonicum L.)" yang mana apakah terdapat pengaruh terhadap pertumbuhan dan hasil pada tanaman bawang merah.

\section{Tujuan Penelitian}

Untuk mengetahui pertumbuhan dan produksi tanaman bawang merah terhadap beberapa jenis pupuk kandang dan ukuran pemotongan ujung umbi serta interaksi kedua perlakuan tersebut.

\section{Hipotesis Penelitian}

1. Jenis pupuk kandang berpengaruh terhadap pertumbuhan dan produksi tanaman bawang merah.

2. Ukuran pemotongan ujung umbi berpengaruh terhadap pertumbuhan dan produksi tanaman bawang merah.

3. Interaksi antara jenis pupuk kandang dan ukuran pemotongan ujung umbi berpengaruh terhadap pertumbuhan dan produksi tanaman bawang merah. 
METODOLOGI PENELITIAN Tempat dan Waktu Penelitian

Penelitian ini dilaksanakan di Gampong Gedubang Aceh, Kecamatan Langsa Baro, Kota Langsa dengan Ketinggian tempat \pm $10 \mathrm{~m}$ dpl dan $\mathrm{pH}$ tanah 6,8 (soil tester). Penelitian ini dilaksanakan mulai bulan Februari sampai dengan bulan April 2019.

\section{Bahan dan Alat}

Bahan : Bahan yang digunakan dalam penelitian ini adalah umbi bibit bawang merah Varietas Bima Brebes, pupuk kandang kambing, pupuk kandang ayam dan pupuk kandang bebek. Sedangkan untuk pupuk susulan yang digunakan adalah Urea, TSP dan KCL. Untuk pengendalian hama dan penyakit digunakan fungisida Dithane 80 WP dan decis EC.

Alat : Alat-alat yang digunakan dalam penelitian ini adalah cangkul, gembor, penggaris, papan nama plot, kertas label, tali, alat tulis, kamera, timbangan, sprayer dan alat lain yang diperlukan dalam pelaksanaan penelitian ini.

\section{Metode Penelitian}

dalam penelitian ini adalah Penelitian ini menggunakan RAK pola faktorial yang terdiri dari dua faktor: jenis pupuk kandang dengan notasi $(\mathrm{k})$ yang terdiri dari 4 taraf adalah k0 : kontrol, k1 : pupuk kandang ayam 2,5 kg/plot, k2 : pupuk kandang kambing 2,5 kg/plot dan k3 : pupuk kandang bebek 2,5 $\mathrm{kg} /$ plot. Sedangkan ukuran pemotongan ujung umbi dengan notasi (p) yang terdiri dari 3 taraf yaitu : p0 : tanpa pemotongan, p1 : pemotongan $1 / 4$ bagian, p2 : pemotongan $1 / 3$ bagian.

Dengan demikian diperoleh 12 kombinasi perlakuan dan diulang 3 kali sehingga diperoleh 36 satuan percobaan. Setiap satuan percobaan terdiri dari 16 tanaman, secara keseluruhan terdapat 576 tanaman dan setiap satu percobaan terdiri dari 4 tanaman sampel sebagai sumber data. Data yang diperoleh dianalisis dengan menggunakan model matematika (Hanafiah, 2010) sebagai berikut:

$$
Y_{i j k}=\mu+\beta_{i}+K_{j}+P_{k}+(K P)_{j k}+
$$

Hasil Analisis Sidik Ragam yang berpengaruh sangat nyata dan nyata terhadap parameter yang diamati, dilanjutkan dengan uji Beda Nyata Jujur (BNJ) pada taraf 5\%.

\section{Pelaksanaan Penelitian Pelaksanaan Penelitian}

\section{Persiapan Lahan}

Sebelum tanah diolah, dilakukan pengukuran $\mathrm{pH}$ tanah menggunakan $\mathrm{pH}$ tancap (soil tester) dengan hasil pengukurah $\mathrm{pH} \quad 6,8$. Kemudian dilakukan pengukuran lahan dengan menggunakan meteran dan tali, lahan yang digunakan dalam penelitian ini mempunyai ukuran panjang $15,3 \mathrm{~m}$ dan lebar $4 \mathrm{~m}$. Pembersihan gulma dilakukan setelah pengukuran lahan. Pembersihan gulma dilakukan secara manual dengan menggunakan cangkul dan parang. Gulma yang dibersihkan adalah teki-tekian.

Pengolahan tanah dilakukan dua kali, pengolahan tanah pertama dilakukan menggunakan cangkul dengan kedalaman 20-30 cm, setelah itu dibiarkan selama 1 minggu, kemudian dilakukan pengolahan tanah kedua dengan menghancurkan 
gumpalan tanah lalu tanah tersebut diratakan.

Plot percobaan dibuat dengan ukuran $1 \times 1 \mathrm{~m}$ atau dengan luas 1 $\mathrm{m}^{2}$, kemudian jarak antar plot sebesar $30 \mathrm{~cm}$ dan jarak antar ulangan sebesar $50 \mathrm{~cm}$ yang tersusun dalam 3 ulangan masing-masing ulangan terdiri dari 12 plot sehingga didapatkan 36 plot percobaan. Tata letak bagan percobaan dapat dilihat pada lampiran 1.

\section{Pemilihan Benih}

Benih bawang merah berasal dari penangkar benih yang berasal dari penagkar benih didaerah Brebes Jawa Tengah, benih yang dipilih adalah benih yang sudah disimpan mengalami penyimpanan minimal selama 2 bulan. Kemudian jika umbi dipotong akan terlihat tunas yang berwarna hijau dengan panjang tunas separuh panjang umbi. Umbi yang dipilih dengan ukuran sedang yaitu panjang umbi 3-4 cm, tidak cacat, kulitnya tidak luka atau sobek.

\section{Aplikasi Perlakuan Pemotongan}

Setelah umbi dipilih kemudian dilakukan pemotongan ujung umbi sesuai perlakuan sebagai berikut : tanpa pemotongan, $1 / 4$ bagian dan $1 / 3$ bagian dari panjang umbi, setelah dipotong sebagian ujungnya, biarkan selama 5 menit sampai bekas potongan menjadi kering untuk menghindari dari pembusukan dan serangan penyakit pada bekas potongan.

\section{Persiapan Pupuk Kandang}

Pupuk kandang didapatkan dari limbah peternak di Gampong Asam Peutik. Sebelum diaplikasikan pupuk kandang perlu didiamkan dan difermentasi selama 8 hari agar mempercepat proses dekomposisi

Cara pembuatan pupuk kandang Wikandari, dkk., (2013) adalah sebagai berikut :
1. Bahan yang digunakan terdiri dari : $10 \mathrm{~mL}$ EM4, $10 \mathrm{~mL}$ larutan gula dan $1 \mathrm{~L}$ aquades dicampurkan dengan $15 \mathrm{~kg}$ kotoran kandang, di atas lantai kering.

2. Setelah tercampur rata dibuat menjadi sebuah gundukan dengan ketinggian $15 \mathrm{~cm}$ dan ditutup dengan karung goni dan adonan diaduk secara berkala.

3. Setelah 8 hari pupuk kandang dapat dibuka dan dipergunakan.

\section{Aplikasi Perlakuan Pupuk Kandang}

Aplikasi perlakuan pemupukan dilakukan 2 minggu sebelum tanam dengan cara menabur pupuk keseluruh bedengan yang sudah siap sesuai perlakuan. Pupuk yang akan digunakan dalam penelitian ini adalah pupuk Kandang ayam dengan dosis 25 ton/ha $(2,5$ $\mathrm{kg} /$ plot), pupuk kandang kambing 25 ton/ha $(2,5 \mathrm{~kg} / \mathrm{plot})$ dan pupuk kandang bebek 25 ton/ha $(2,5$ $\mathrm{kg} /$ plot).

\section{Pemupukan}

Pemupukan susulan dilakukan pada usia 21 hari setelah tanam (HST). Adapun pupuk yang digunakan sebagai berikut : UREA dengan dosis $80 \mathrm{~kg} / \mathrm{ha}(8 \mathrm{~g} / \mathrm{plot})$, TSP dengan dosis $100 \mathrm{~kg} / \mathrm{ha}(10$ g/plot) dan pupuk $\mathrm{KCl}$ diberikan dengan dosis $100 \mathrm{~kg} / \mathrm{ha}(10 \mathrm{~g} / \mathrm{ha})$.

\section{Penanaman}

Penanaman dilakukan dengan menanam satu umbi perlubang tanam dengan kedalaman $5 \mathrm{~cm}$ kemudian jarak tanam $20 \times 20 \mathrm{~cm}$ perlubang tanam. Umbi benih yang telah disiapkan lalu dipotong sebagian ujungnya sesuai perlakuan dan umbi yang sudah dipotong dibiarkan sampai bekas potonganya mengering 
kemudian diletakkan dalam lubang tanam dengan ujung di atas dan ditutup kembali dengan tanah yang gembur $3 / 4$ bagian dari umbi tersebut.

\section{Pemeliharaan}

Pemeliharaan

tanaman

bawang merah meliputi penyiraman, penyisipan, penyiangan gulma, serta pengendalian hama dan penyakit.

- Penyiraman

Dilakukan 2 kali sehari, yaitu pada pagi dan sore hari. Tanah disiram sampai kondisi lembab. Penyiramanan tidak dilakukan apabila terjadi hujan.

- Penyisipan.

Penyisipan dilakukan pada tanaman yang mati, layu, rusak dan kurang baik (abnormal) pertumbuhannya. Penyisipan dilakukan maksimal sampai umur 2 minggu setelah tanam (MST) dengan bibit yang sama. Jumlah bibit yang disiapkan untuk penyulaman adalah 64 bibit (10\%) dari kebutuhan bibit. Banyaknya bibit yang disulam dalam penelitian ini yaitu 58 tanaman.

- Penyiangan

Penyiangan dilakukan setiap sudah ada rumput maka penyiangan segera dilakukan, hal ini bertujuan agar plot tetap bersih dari rumputrumput liar dan gulma lainnya yang tumbuh di atas atau dalam bedengan dengan cara mencabut mengunakan tangan.

\section{Pengendalian Hama dan Penyakit}

Hama yang menyerang pada saat penelitian tidak ada maka tidak dilakukan pengendalian. Penyakit yang menyerang adalah bercak daun.
Pengedalian penyakit dilakukan dengan menggunakan Dithan M-45 80 WP dengan dosis 2 g/liter air. Penyemprotan dilakukan sebanyak 6 kali dengan interval waktu penyemprotan 4 hari sekali yang dilakukan mulai umur 21 hari setelah tanaman.

\section{Panen}

Panen dilakukan pada umur 60 hari setelah tanam (HST) dengan ciri-ciri daun bagian atas rebah dan mengering. Panen dilakukan dengan cara mencabut tanaman secara hatihati agar umbinya tidak rusak atau tertinggal. Umbi yang telah dipanen, dibersihkan dan dipotong daun bagian atasnya untuk dikeringkan. Pengeringan umbi dilakukan dengan cara dikeringanginkan selama kurang lebih 7 hari.

\section{HASIL DAN PEMBAHASAN}

\section{Pengaruh Pengolahan Tanah Tinggi Tanaman}

Rata-rata tinggi tanaman bawang merah pada umur 15, 30 dan 45 HST akibat perlakuan jenis pupuk kandang disajikan pada Tabel 2. 
Tabel 2. Rata-rata Tinggi Tanaman Bawang Merah pada Umur 15, 30 dan 45 HST akibat Pengaruh Jenis Pupuk Kandang

\begin{tabular}{cccc}
\hline \multirow{2}{*}{ Perlakuan } & \multicolumn{3}{c}{ Tinggi Tanaman $(\mathrm{cm})$} \\
\cline { 2 - 4 } & $15 \mathrm{HST}$ & $30 \mathrm{HST}$ & $45 \mathrm{HST}$ \\
\hline $\mathrm{K}_{0}$ & 12,63 & 20,51 & $24,61 \mathrm{ab}$ \\
$\mathrm{K}_{1}$ & 14,38 & 20,63 & $24,21 \mathrm{a}$ \\
$\mathrm{K}_{2}$ & 13,95 & 20,13 & $24,43 \mathrm{a}$ \\
$\mathrm{K}_{3}$ & 14,63 & 21,69 & $25,72 \mathrm{~b}$ \\
\hline BNJ $_{0,05}$ & tn & tn & 1,28 \\
\hline
\end{tabular}

Keterangan : Angka yang diikuti oleh huruf yang sama pada kolom yang sama berbeda tidak nyata pada uji (BNJ) pada taraf $5 \%$.

Tabel 2 menunjukkan bahwa tinggi tanaman bawang merah umur 45 HST tertinggi dijumpai pada perlakuan $\mathrm{K}_{3}$ (pupuk kandang bebek dengan dosis 25 ton/ha), yang secara uji BNJ 0,05 berbeda nyata dengan perlakuan $\mathrm{K}_{1}$ (pupuk kandang ayam dengan dosis 25 ton/ha) dan $\mathrm{K}_{2}$ (pupuk kandang kambing dengan dosis 25 ton/ha) namun berbeda tidak nyata dengan perlakuan $\mathrm{K}_{0}$ (tanpa pupuk kandang dengan dosis 0 ton/ha). Berdasarkan hasil pengamatan dilapangan hal ini diduga akibat jenis pakan yang berbeda-beda dari setiap jenis ternak, sehingga mempengaruhi kandungan dari pupuk kandang tersebut terutama pupuk kandang bebek yang secara pengamatan dilapangan menggunakan sumber pakan alami. Mulyani dan Kartasapoetra (1991) yang menyatakan, unsur hara yang terkandung dalam pupuk kandang bebek sangat tergantung dari jenis pakan, sifat kotoran, cara penyimpanan, pengolahan dan pemakaiannya.

\section{Jumlah Daun}

Rata- rata jumlah daun bawang merah pada umur 15, 30 dan 45 HST akibat perlakuan jenis pupuk kandang disajikan pada Tabel 3.

Tabel 3. Rata-rata Jumlah Daun Tanaman Bawang Merah pada umur 15, 30 dan 45 HST akibat Pengaruh Jenis Pupuk Kandang

\begin{tabular}{cccc}
\hline \multirow{2}{*}{ Perlakuan } & \multicolumn{3}{c}{ Jumlah Daun (helai) } \\
\cline { 2 - 4 } & $15 \mathrm{HST}$ & $30 \mathrm{HST}$ & $45 \mathrm{HST}$ \\
\hline $\mathrm{K}_{0}$ & $5,53 \mathrm{ab}$ & $10,14 \mathrm{a}$ & $15,14 \mathrm{a}$ \\
$\mathrm{K}_{1}$ & $5,75 \mathrm{~b}$ & $11,22 \mathrm{ab}$ & $16,22 \mathrm{ab}$ \\
$\mathrm{K}_{2}$ & $4,97 \mathrm{a}$ & $10,81 \mathrm{ab}$ & $15,81 \mathrm{ab}$ \\
$\mathrm{K}_{3}$ & $5,97 \mathrm{~b}$ & $11,97 \mathrm{~b}$ & $17,00 \mathrm{~b}$ \\
\hline BNJ $_{0,05}$ & 0,72 & 1,38 & 1,39 \\
\hline
\end{tabular}

Keterangan : Angka yang diikuti oleh huruf yang sama pada kolom yang sama berbeda tidak nyata pada uji (BNJ) pada taraf $5 \%$. 
Tabel 3 menunjukan bahwa jumlah daun bawang merah umur 15 HST tertinggi dijumpai pada perlakuan $\mathrm{K}_{3}$, yang secara uji $\mathrm{BNJ}$ 0,05 berbeda nyata dengan perlakuan $\mathrm{K}_{2}$ namun tidak berbeda nyata dengan perlakuan $\mathrm{K}_{0} \quad$ dan $\mathrm{K}_{1}$. Sedangkan jumlah daun bawang merah pada umur 30 dan 45 HST tertinggi pada perlakuan $\mathrm{K}_{3}$ yang berbeda nyata dengan perlakuan $\mathrm{K}_{0}$ dan berbeda tidak nyata pada perlakuan $\mathrm{K}_{1}$ dan $\mathrm{K}_{2}$. Banyaknya jumlah daun bawang merah yang dibantu pupuk kandang bebek mampu terdekomposisi dengan baik didalam tanah sehingga dapat memenuhi kebutuhan unsur hara bagi tanaman dan meningkatkan pertumbuhan tanaman bawang merah.

Beberapa hasil penelitian aplikasi pupuk kandang dari hewan unggas seperti bebek selalu memberikan respon tanaman yang terbaik pada musim pertama. Hal ini terjadi karena pupuk kandang bebek relatif lebih cepat terdekomposisi serta mempunyai kadar hara yang cukup pula jika dibandingkan dengan jumlah unit yang sama dengan pupuk kandang lainnya (Widarti, $d k k$., 2015).

Jumlah Umbi Pertanaman Sampel Rata-rata jumlah umbi pertanaman sampel bawang merah akibat perlakuan jenis pupuk kandang disajikan pada Tabel 4.

Tabel 4. Rata-rata Jumlah Umbi Pertanaman Sampel Tanaman Bawang Merah akibat Pengaruh Jenis Pupuk Kandang

Perlakuan

Jumlah Umbi Pertanaman Sampel (anakan)

\begin{tabular}{cc}
\hline $\mathrm{K}_{0}$ & $3,92 \mathrm{a}$ \\
$\mathrm{K}_{1}$ & $4,22 \mathrm{ab}$ \\
$\mathrm{K}_{2}$ & $4,67 \mathrm{ab}$ \\
$\mathrm{K}_{3}$ & $4,83 \mathrm{~b}$ \\
\hline $\mathrm{BNJ}_{0,05}$ & 0,80
\end{tabular}

Keterangan : Angka yang diikuti oleh huruf yang sama pada kolom yang sama berbeda tidak nyata pada uji (BNJ) pada taraf $5 \%$.

Tabel 4 menunjukkan bahwa jumlah umbi pertanaman sampel tanaman bawang merah tertinggi dijumpai pada perlakuan $\mathrm{K}_{3}$, yang secara uji BNJ 0,05 berbeda nyata dengan perlakuan $\mathrm{K}_{0}$ namun berbeda tidak nyata pada perlakuan $\mathrm{K}_{1}$ dan $\mathrm{K}_{2}$. Penggunaan pupuk kandang bebek kedalam tanah dapat meningkatkan jumlah umbi tanaman bawang merah. Hal ini karena kandungan $\mathrm{C} / \mathrm{N}$ pupuk kandang bebek $<20$ dibandingkan pupuk kandang kambing dan ayam sehingga mikroorganisme sebagai dekomposer dapat membantu mempercepat proses penyerapan unsur hara dari tanah.

Nilai rasio $\mathrm{C} / \mathrm{N}$ bahan organik merupakan faktor penting dalam pengomposan. Karbon digunakan sebagai sumber energi dan nitrogen sebagai sumber nutrisi untuk pembentukkan sel-sel tubuh 
mikroorganisme selama proses

pengomposan (Pradhana, 2017).

Berat Segar Umbi Tanaman per

Sampel dan Berat Umbi Segar per

Plot

jenis pupuk kandang berpengaruh sangat nyata pada berat segar umbi tanaman per sampel berat umbi segar per plot bawang merah. Rata - rata berat segar umbi tanaman per sampel dan berat umbi segar per plot bawang merah disajikan pada tabel 5

Tabel 5. Rata-rata Berat Segar Umbi Tanaman per Sampel dan Berat Umbi Segar per Plot Bawang Merah akibat Pengaruh Jenis Pupuk Kandang

\begin{tabular}{ccc}
\hline Perlakuan & $\begin{array}{c}\text { Berat Segar Umbi } \\
\text { Tanaman Per Sampel }(\mathrm{g})\end{array}$ & $\begin{array}{c}\text { Berat Segar Umbi } \\
\text { Tanaman Per Plot }(\mathrm{g})\end{array}$ \\
\hline $\mathrm{K}_{0}$ & $7,22 \mathrm{a}$ & $97,21 \mathrm{a}$ \\
$\mathrm{K}_{1}$ & $7,59 \mathrm{ab}$ & $106,97 \mathrm{a}$ \\
$\mathrm{K}_{2}$ & $8,23 \mathrm{ab}$ & $111,00 \mathrm{a}$ \\
$\mathrm{K}_{3}$ & $9,35 \mathrm{~b}$ & $143,98 \mathrm{~b}$ \\
\hline $\mathrm{BNJ}_{0,05}$ & 2,07 & 30,27 \\
\hline
\end{tabular}

Keterangan : Angka yang diikuti oleh huruf yang sama pada kolom yang sama berbeda tidak nyata pada uji (BNJ) pada taraf $5 \%$.

Tabel 5 menunjukkan bahwa berat segar umbi tanaman per sampel tertinggi dijumpai pada perlakuan $\mathrm{K}_{3}$, yang secara uji $\mathrm{BNJ}_{0,05}$ berbeda nyata pada perlakuan $\mathrm{K}_{0}$ namun berbeda tidak nyata dengan perlakuan $K_{1}$ dan $K_{2}$. Sedangkan berat umbi segar per plot bawang merah tertinggi dijumpai pada perlakuan $\mathrm{K}_{3}$, yang secara uji $\mathrm{BNJ}$ 0,05 berbeda nyata pada perlakuan $\mathrm{K}_{0}$, $\mathrm{K}_{1}$ dan $\mathrm{K}_{2}$. sehingga terjadi kenaikan kandungan fosfor pada pupuk kandang. Unsur fosfor (P) sebagai bahan organik memiliki peranan yang sangat penting dalam kesuburan tanah, proses fotosintesis, dan fisiologi kimiawi tanaman. Fosfor juga dibutuhkan di dalam pembelahan sel, pengembangan jaringan dan titik tumbuh tanaman (Widarti $d k k$., 2015).

\section{Berat Kering Umbi}

Tanaman per Sampel dan Berat Umbi Kering per Plot

Rata-rata berat kering umbi tanaman per sampel dan berat umbi kering per plot bawang merah akibat perlakuan jenis pupuk kandang disajikan pada Tabel 6 . 
Tabel 6. Rata-rata Berat Kering Umbi Tanaman Per Sampel Dan Berat Umbi Kering Per Plot Bawang Merah akibat Pengaruh Jenis Pupuk Kandang

\begin{tabular}{ccc}
\hline Perlakuan & $\begin{array}{c}\text { Berat Umbi Kering } \\
\text { Tanaman Per Sampel }(\mathrm{g})\end{array}$ & $\begin{array}{c}\text { Berat Umbi Kering } \\
\text { Tanaman Per Plot }(\mathrm{g})\end{array}$ \\
\hline $\mathrm{K}_{0}$ & $5,72 \mathrm{a}$ & $88,47 \mathrm{a}$ \\
$\mathrm{K}_{1}$ & $5,98 \mathrm{ab}$ & $98,25 \mathrm{a}$ \\
$\mathrm{K}_{2}$ & $6,27 \mathrm{ab}$ & $102,63 \mathrm{a}$ \\
$\mathrm{K}_{3}$ & $8,17 \mathrm{~b}$ & $136,18 \mathrm{~b}$ \\
\hline BNJ $_{0,05}$ & 2,28 & 30,38
\end{tabular}

Keterangan : Angka yang diikuti oleh huruf yang sama pada kolom yang sama berbeda tidak nyata pada uji (BNJ) pada taraf $5 \%$.

Tabel 6 menunjukkan bahwa berat kering umbi tanaman per sampel bawang merah tertinggi dijumpai pada perlakuan $\mathrm{K}_{3}$, yang secara uji BNJ 0,05 berbeda nyata pada perlakuan $\mathrm{K}_{0}$ namun tidak berbeda nyata dengan perlakuan $\mathrm{K}_{1}$ dan $\mathrm{K}_{2}$. Sedangkan berat umbi kering per plot bawang merah tertinggi dijumpai pada perlakuan $K_{3}$, yang secara uji BNJ 0,05 berbeda nyata pada perlakuan $\mathrm{K}_{0}, \mathrm{~K}_{1}$ dan $\mathrm{K}_{2}$. Pemberian pupuk kandang bebek mampu meningkatkan berat kering per sampel dan per plot pada bawang merah. Hal ini terjadi ketika hara yang diperlukan telah terpenuhi maka akar akan mampu menyerap dengan mudah yang selanjutnya diteruskan keseluruh bagian tanaman lainnya, sehingga meningkatkan bobot bawang merah.

Menurut Steffano (2017) Pemberian pupuk kotoran bebek yang memiliki hara $\mathrm{P}_{2} \mathrm{O}_{5}$ sebesar $1,02 \%$ mampu meningkatkan metabolisme pertumbuhan generatif tanaman dapat tumbuh dengan baik. Sutejo (1999), melaporkan $\mathrm{P}_{2} \mathrm{O}_{5}$ sebesar $1,02 \%$ bagi tanaman juga dapat memperbaiki pertumbuhan generatif terutama pembentukan bunga, buah, dan biji. Apabila pertumbuhan vegetatif baik, hasil fotosintesis semakin banyak, hal ini menyebabkan kemampuan tanaman untuk membentuk organ-organ generatif semakin meningkat.

\section{Pengaruh Ukuran Pemotongan Ujung Umbi Bawang Merah Tinggi Tanaman}

Rata-rata tinggi tanaman bawang merah pada umur 15, 30 dan 45 HST akibat perlakuan ukuran pemotongan ujung umbi bawang merah disajikan pada Tabel 7. 
Tabel 7. Rata-rata Tinggi Tanaman Bawang Merah pada Umur 15, 30 dan 45 HST akibat Ukuran Pemotongan Ujung Umbi Bawang Merah

\begin{tabular}{cccc}
\hline \multirow{2}{*}{ Perlakuan } & \multicolumn{3}{c}{ Tinggi Tanaman $(\mathrm{cm})$} \\
\cline { 2 - 4 } & $15 \mathrm{HST}$ & $30 \mathrm{HST}$ & $45 \mathrm{HST}$ \\
\hline $\mathrm{P}_{0}$ & $12,97 \mathrm{a}$ & $20,07 \mathrm{a}$ & $24,42 \mathrm{a}$ \\
$\mathrm{P}_{1}$ & $15,18 \mathrm{~b}$ & $22,04 \mathrm{~b}$ & $25,9 \mathrm{~b}$ \\
$\mathrm{P}_{2}$ & $13,54 \mathrm{a}$ & $20,10 \mathrm{a}$ & $23,92 \mathrm{a}$ \\
\hline BNJ $_{0,05}$ & 1,58 & 1,40 & 1,00 \\
\hline
\end{tabular}

Keterangan : Angka yang diikuti oleh huruf yang sama pada kolom yang sama berbeda tidak nyata pada uji (BNJ) pada taraf $5 \%$.

Tabel 7 menunjukkan bahwa tinggi tanaman pada umur 15, 30 dan 45 HST tertinggi dijumpai pada perlakuan $\mathrm{P}_{1} \quad$ (pemotongan $1 / 4$ bagian), yang secara uji $\mathrm{BNJ} 0,05$ berbeda nyata dengan perlakuan $\mathrm{P}_{0}$ (tanpa pemotongan) dan $\mathrm{P}_{2}$ (pemotongan $1 / 3$ bagian). Pemberian perlakuan pemotongan $1 / 4$ bagian dapat meningkatkan pertumbuhan tinggi tanaman bawang merah.

Menurut Jumini, $d k k$., (2010) menyatakan bahwa Hal ini diduga pemotongan $1 / 4$ bagian umbi mampu merangsang pembentukan hormon tumbuh tanpa mengganggu mata tunas. Sebaliknya, pemotongan umbi bibit $1 / 3$ bagian diduga mengganggu mata tunas sehingga pertumbuhannya terganggu.

\section{Jumlah daun}

Rata-rata jumlah daun bawang merah pada umur 15, 30 dan 45 HST akibat perlakuan ukuran pemotongan ujung umbi bawang merah disajikan pada Tabel 8.

Tabel 8. Rata-rata Jumlah Daun Tanaman Bawang Merah pada umur 15, 30 dan 45 HST akibat Ukuran Pemotongan Ujung Umbi Bawang Merah

\begin{tabular}{cccc}
\hline \multirow{2}{*}{ Perlakuan } & \multicolumn{3}{c}{ Jumlah Daun (helai) } \\
\cline { 2 - 4 } & $15 \mathrm{HST}$ & $30 \mathrm{HST}$ & $45 \mathrm{HST}$ \\
\hline $\mathrm{P}_{0}$ & $4,67 \mathrm{a}$ & $9.58 \mathrm{a}$ & $14,58 \mathrm{a}$ \\
$\mathrm{P}_{1}$ & $6,33 \mathrm{~b}$ & $12,44 \mathrm{c}$ & $17,44 \mathrm{c}$ \\
$\mathrm{P}_{2}$ & $5,67 \mathrm{~b}$ & $11,08 \mathrm{~b}$ & $16,10 \mathrm{~b}$ \\
\hline $\mathrm{BNJ}_{0,05}$ & 0,71 & 1,08 & 1,09 \\
\hline
\end{tabular}

Keterangan : Angka yang diikuti oleh huruf yang sama pada kolom yang sama berbeda tidak nyata pada uji (BNJ) pada taraf $5 \%$.

Tabel 8 menunjukkan bahwa jumlah daun bawang merah pada umur 15 HST tertinggi dijumpai pada perlakuan $\mathrm{P}_{1}$, yang secara uji BNJ 0,05 berbeda nyata pada perlakuan $\mathrm{P}_{0}$ namun tidak berbeda nyata dengan perlakuan $\mathrm{P}_{2}$. Sedangkan pada umur 30 dan 45 HST jumlah daun tertinggi pada perlakuan $\mathrm{P}_{1}$, yang secara uji $\mathrm{BNJ}_{0,05}$ 
berbeda nyata pada perlakuan $\mathrm{P}_{0}$ dan $\mathrm{P}_{2}$. Pemotongan ujung umbi $1 / 4$ dapat memperbanyak jumlah daun dan mempercepat pertumbuhan tanaman pada fase vegetatif

Menurut Rukmana (1994) menambahkan bahwa pemotongan umbi bibit $1 / 4$ bagian pada bawang merah mempunyai beberapa keuntungan antara lain: pertumbuhan bibit merata, umbi bibit lebih cepat tumbuh dan berpengaruh terhadap banyaknya anakan dan jumlah daun, sehingga hasil meningkat.

\section{Jumlah Umbi Pertanaman Sampel}

Rata-rata jumlah umbi pertanaman sampel bawang merah akibat perlakuan ukuran pemotongan ujung umbi disajikan pada Tabel 9.

Tabe1 9. Rata-rata Jumlah Umbi Pertanaman Sampel Tanaman Bawang Merah akibat Ukuran Pemotongan Ujung Umbi

Perlakuan Jumlah Umbi Pertanaman Sampel (anakan)

\begin{tabular}{cc}
\hline $\mathrm{P}_{0}$ & $4,04 \mathrm{a}$ \\
$\mathrm{P}_{1}$ & $4,96 \mathrm{~b}$ \\
$\mathrm{P}_{2}$ & $4,23 \mathrm{a}$ \\
\hline $\mathrm{BNJ}_{0,05}$ & 0,62 \\
\hline
\end{tabular}

Keterangan : Angka yang diikuti oleh huruf yang sama pada kolom yang sama berbeda tidak nyata pada uji (BNJ) pada taraf $5 \%$.

Tabel 9 menunjukkan bahwa jumlah umbi pertanaman sampel bawang merah tertinggi dijumpai pada perlakuan $\mathrm{P}_{1}$, yang secara uji BNJ 0,05 berbeda nyata pada perlakuan $\mathrm{P}_{2}$ dan $\mathrm{P}_{0}$. Hal menunjukkan bahwa pemotongan ujung umbi $1 / 4$ bagian memacu pertumbuhan jumlah anakan tanaman dimana setiap lapisan umbi akan mengalami pertumbuhan

\section{Berat Segar Umbi Tanaman per Sampel dan Berat Umbi Segar per Plot}

Rata-rata berat segar umbi tanaman per sampel dan berat umbi segar per plot bawang merah akibat perlakuan ukuran pemotongan ujung umbi disajikan pada Tabel 10. menghasilkan anakan. Pemotongan umbi meregenerasi titik tumbuh tanaman sehingga memacu jumlah anakan pada setiap umbi.

Hal ini sejalan dengan
pendapat Wibowo $(2005)$
menyatakan bahwa pemotongan
umbi $1 / 4$ bagian dapat mempercepat
pertumbuhan tanaman dan jumlah
anakan, serta dapat mendorong
pertumbuhan umbi samping.


Tabel 10. Rata-rata Berat Segar Umbi Tanaman per Sampel dan Berat Umbi Segar per Plot Bawang Merah akibat Ukuran Pemotongan Ujung Umbi

\begin{tabular}{ccc}
\hline Perlakuan & $\begin{array}{c}\text { Berat Segar Umbi } \\
\text { Tanaman Sampel }(\mathrm{g})\end{array}$ & $\begin{array}{c}\text { Berat Segar Umbi } \\
\text { Tanaman Per Plot }(\mathrm{g})\end{array}$ \\
\hline $\mathrm{P}_{0}$ & $7,23 \mathrm{a}$ & $87,59 \mathrm{a}$ \\
$\mathrm{P}_{1}$ & $9,31 \mathrm{~b}$ & $153,89 \mathrm{~b}$ \\
$\mathrm{P}_{2}$ & $7,75 \mathrm{ab}$ & $102,89 \mathrm{a}$ \\
\hline $\mathrm{BNJ}_{0,05}$ & 1,62 & 23,73 \\
\hline
\end{tabular}

Keterangan : Angka yang diikuti oleh huruf yang sama pada kolom yang sama berbeda tidak nyata pada uji (BNJ) pada taraf $5 \%$.

Tabel 10 menunjukkan bahwa berat segar umbi tanaman per sampel tertinggi dijumpai pada perlakuan $\mathrm{P}_{1}$, yang secara uji BNJ 0,05 berbeda nyata pada perlakuan $\mathrm{P}_{0}$ namun tidak berbeda nyata dengan perlakuan $\mathrm{P}_{2}$. Sedangkan berat segar umbi tanaman per plot tertinggi dijumpai pada perlakuan $\mathrm{P}_{1}$, yang secara uji $\mathrm{BNJ}{ }_{0,05}$ berbeda nyata pada perlakuan $\mathrm{P}_{0}$ dan $\mathrm{P}_{2}$. Pemotongan $1 / 4$ bagian dapat mempercepat fase vegetatif tanaman yang membentuk organ-organ vegetatif seperti daun yang berfungsi dalam proses fotosintesis sehingga mempengaruhi berat umbi segar tanaman bawang merah.

Berat brangkasan basah suatu tanaman sangat ditentukan oleh laju fotosintesis, laju penyerapan unsur hara dan air atau kandungan air pada tanaman. Kandungan air di dalam tanaman dipengaruhi oleh lingkungan terutama suhu dan kelembaban udara. Karena pada suhu yang tinggi akan mempengaruhi laju transpirasi pada organ tanaman. Sifat dari persediaan zat makanan yang terkandung di dalam bulbus, yaitu bersifat basah karena mengandung air, sehingga air memberikan kontribusi terhadap berat brangkasan basah (Sutedjo dan Kartasapoetra, 1990).

Berat Kering Umbi Tanaman per Sampel dan Berat Umbi Kering per Plot

Rata-rata berat kering umbi tanaman per sampel dan berat umbi kering per plot bawang merah akibat perlakuan ukuran pemotongan ujung umbi disajikan pada Tabel 11. 
Tabel 11. Rata-rata Berat Kering Umbi Tanaman per Sampel dan Berat Umbi Kering per Plot Bawang Merah akibat Ukuran Pemotongan Ujung Umbi

\begin{tabular}{ccc}
\hline Perlakuan & $\begin{array}{c}\text { Berat Umbi Kering } \\
\text { Tanaman Sampel }(\mathrm{g})\end{array}$ & $\begin{array}{c}\text { Berat Umbi Kering } \\
\text { Tanaman Per Plot }(\mathrm{g})\end{array}$ \\
\hline $\mathrm{P}_{0}$ & $5,44 \mathrm{a}$ & $78,17 \mathrm{a}$ \\
$\mathrm{P}_{1}$ & $7,90 \mathrm{~b}$ & $146,53 \mathrm{~b}$ \\
$\mathrm{P}_{2}$ & $6,26 \mathrm{ab}$ & $94,45 \mathrm{a}$ \\
\hline $\mathrm{BNJ}_{0,05}$ & 1,79 & 23,81 \\
\hline
\end{tabular}

Keterangan : Angka yang diikuti oleh huruf yang sama pada kolom yang sama berbeda tidak nyata pada uji (BNJ) pada taraf $5 \%$.

Tabel 11 menunjukkan bahwa berat kering umbi tanaman per sampel tertinggi dijumpai pada perlakuan $\mathrm{P}_{1}$, yang secara uji $\mathrm{BNJ}{ }_{0,05}$ berbeda nyata pada perlakuan $\mathrm{P}_{0}$ namun tidak berbeda nyata dengan perlakuan $\mathrm{P}_{2}$. Sedangkan berat kering umbi tanaman per plot tertinggi dijumpai pada perlakuan $\mathrm{P}_{1}$, yang secara uji BNJ 0,05 berbeda nyata pada perlakuan $\mathrm{P}_{0}$ dan $\mathrm{P}_{2}$. Dengan diberikan perlakuan pemotongan ujung umbi $1 / 4$ bagian pada tanaman bawang merah dapat merangsang percepatan pada fase vegetatif dan meningkatkan proses asimilasi seperti fotosintesis pada tanaman bawang merah. Berat brangkasan kering tanaman mencerminkan akumulasi senyawa organik yang berhasil disintesis tanaman dari senyawa anorganik, terutama air dan karbon dioksida dan unsur hara yang telah diserap akar, baik yang digunakan dalam sintesis senyawa organik maupun yang tetap dalam bentuk ionik dalam jaringan tanaman akan memberikan kontribusi terhadap pertambahan berat kering tanaman. Dengan meningkatnya pembentukan fotosintat akan meningkatkan berat brangkasan kering tanaman (Lakitan, 1996).

Interaksi Akibat Pengaruh Jenis Pupuk Kandang Dan Ukuran Pemotongan Ujung Umbi Bawang Merah

\section{Tinggi Tanaman}

Rata-rata tinggi tanaman bawang merah pada umur 15 , 30 dan 45 HST akibat perlakuan kombinasi jenis pupuk kandang dan ukuran pemotongan ujung umbi disajikan pada Tabel 12. 
Tabel 12. Rata-Rata Tinggi Tanaman Bawang Merah pada Umur 15, 30 dan 45 HST akibat Pengaruh Jenis Pupuk Kandang dan Ukuran Pemotongan Ujung Umbi terhadap Pertumbuhan dan Produksi Tanaman Bawang Merah

\begin{tabular}{cccc}
\hline Kombinasi & \multicolumn{3}{c}{ Tinggi Tanaman $(\mathrm{cm})$} \\
\cline { 2 - 4 } Perlakuan & $15 \mathrm{HST}$ & $30 \mathrm{HST}$ & $45 \mathrm{HST}$ \\
\hline $\mathrm{K}_{0} \mathrm{P}_{0}$ & 11,38 & $19,88 \mathrm{abc}$ & $24,63 \mathrm{abcd}$ \\
$\mathrm{K}_{0} \mathrm{P}_{1}$ & 14,75 & $22,08 \mathrm{bc}$ & $26,00 \mathrm{abcd}$ \\
$\mathrm{K}_{0} \mathrm{P}_{2}$ & 11,75 & $19,58 \mathrm{ab}$ & $23,21 \mathrm{ab}$ \\
$\mathrm{K}_{1} \mathrm{P}_{0}$ & 14,17 & $21,25 \mathrm{bc}$ & $24,50 \mathrm{abcd}$ \\
$\mathrm{K}_{1} \mathrm{P}_{1}$ & 15,29 & $20,96 \mathrm{bc}$ & $24,88 \mathrm{abcd}$ \\
$\mathrm{K}_{1} \mathrm{P}_{2}$ & 13,67 & $19,67 \mathrm{abc}$ & $23,25 \mathrm{ab}$ \\
$\mathrm{K}_{2} \mathrm{P}_{0}$ & 11,29 & $17,21 \mathrm{a}$ & $22,21 \mathrm{a}$ \\
$\mathrm{K}_{2} \mathrm{P}_{1}$ & 15,52 & $21,88 \mathrm{bc}$ & $25,79 \mathrm{abcd}$ \\
$\mathrm{K}_{2} \mathrm{P}_{2}$ & 15,04 & $21,29 \mathrm{bc}$ & $25,29 \mathrm{abcd}$ \\
$\mathrm{K}_{3} \mathrm{P}_{0}$ & 15,04 & $21,96 \mathrm{bc}$ & $26,33 \mathrm{abcd}$ \\
$\mathrm{K}_{3} \mathrm{P}_{1}$ & 15,17 & $23,25 \mathrm{c}$ & $26,92 \mathrm{~d}$ \\
$\mathrm{~K}_{3} \mathrm{P}_{2}$ & 13,68 & $19,88 \mathrm{abc}$ & $23,92 \mathrm{abcd}$ \\
\hline $\mathrm{BNJ} 0,05$ & $\mathrm{tn}$ & 3,64 & 2,59 \\
\hline
\end{tabular}

Keterangan : Angka yang diikuti oleh huruf yang sama pada kolom yang sama berbeda tidak nyata pada uji (BNJ) pada taraf $5 \%$.

Tabel 12 menunjukkan bahwa ratarata tinggi tanaman umur $30 \mathrm{HST}$ tertinggi dijumpai pada kombinasi perlakuan $\mathrm{K}_{3} \mathrm{P}_{1}$, yang secara uji $\mathrm{BNJ}$ 0,05 berbeda nyata dengan kombinasi perlakuan $\mathrm{K}_{0} \mathrm{P}_{2}$ dan $\mathrm{K}_{2} \mathrm{P}_{0}$ namun tidak berbeda nyata dengan kombinasi perlakuan $\mathrm{K}_{0} \mathrm{P}_{0}, \mathrm{~K}_{0} \mathrm{P}_{1}$, $\mathrm{K}_{1} \mathrm{P}_{0}, \mathrm{~K}_{1} \mathrm{P}_{1}, \mathrm{~K}_{1} \mathrm{P}_{2}, \mathrm{~K}_{2} \mathrm{P}_{1}, \mathrm{~K}_{2} \mathrm{P}_{2}, \mathrm{~K}_{3} \mathrm{P}_{0}$ dan $\mathrm{K}_{3} \mathrm{P}_{2}$. Sedangkan rata-rata tinggi tanaman pada umur 45 HST dijumpai pada kombinasi perlakuan $\mathrm{K}_{3} \mathrm{P}_{1}$, yang secara uji BNJ 0,05 berbeda nyata dengan kombinasi perlakuan $\mathrm{K}_{0} \mathrm{P}_{2}, \quad \mathrm{~K}_{1} \mathrm{P}_{2}$ dan $\mathrm{K}_{2} \mathrm{P}_{0}$ namun tidak berbeda nyata dengan perlakuan $\mathrm{K}_{0} \mathrm{P}_{0}, \mathrm{~K}_{0} \mathrm{P}_{1}, \mathrm{~K}_{1} \mathrm{P}_{0}, \mathrm{~K}_{1} \mathrm{P}_{1}$, $\mathrm{K}_{2} \mathrm{P}_{1}, \quad \mathrm{~K}_{2} \mathrm{P}_{2}, \quad \mathrm{~K}_{3} \mathrm{P}_{0}$ dan $\mathrm{K}_{3} \mathrm{P}_{2}$. Kombinasi perlakuan $\mathrm{K}_{3} \mathrm{P}_{1}$ merupakan kombinasi yang tepat untuk meningkatkan pertumbuhan tinggi tanaman.

\section{JumlahDaun}

Rata-rata jumlah daun bawang merah pada umur 15, 30 dan 45 HST akibat perlakuan kombinasi jenis pupuk kandang dan ukuran pemotongan ujung umbi disajikan pada Tabel 13. 
Tabel 13. Rata-rata Jumlah Daun Tanaman Bawang Merah pada Umur 15, 30 dan 45 HST akibat Pengaruh Jenis Pupuk Kandang dan Ukuran Pemotongan Ujung Umbi Terhadap Pertumbuhan dan Produksi Tanaman Bawang Merah

\begin{tabular}{cccc}
\hline Kombinasi & \multicolumn{3}{c}{ Jumlah Daun $(\mathrm{cm})$} \\
\cline { 2 - 4 } Perlakuan & $15 \mathrm{HST}$ & $30 \mathrm{HST}$ & $45 \mathrm{HST}$ \\
\hline $\mathrm{K}_{0} \mathrm{P}_{0}$ & $4,25 \mathrm{a}$ & $9,42 \mathrm{a}$ & $14,42 \mathrm{a}$ \\
$\mathrm{K}_{0} \mathrm{P}_{1}$ & $5,67 \mathrm{abcd}$ & $10,00 \mathrm{ab}$ & $15,00 \mathrm{ab}$ \\
$\mathrm{K}_{0} \mathrm{P}_{2}$ & $6,67 \mathrm{~cd}$ & $11,00 \mathrm{ab}$ & $16,00 \mathrm{ab}$ \\
$\mathrm{K}_{1} \mathrm{P}_{0}$ & $4,83 \mathrm{ab}$ & $9,67 \mathrm{a}$ & $14,67 \mathrm{a}$ \\
$\mathrm{K}_{1} \mathrm{P}_{1}$ & $6,25 \mathrm{bcd}$ & $12,58 \mathrm{abc}$ & $17,58 \mathrm{bc}$ \\
$\mathrm{K}_{1} \mathrm{P}_{2}$ & $6,17 \mathrm{bcd}$ & $11,42 \mathrm{ab}$ & $16,42 \mathrm{ab}$ \\
$\mathrm{K}_{2} \mathrm{P}_{0}$ & $4,50 \mathrm{ab}$ & $9,67 \mathrm{a}$ & $14,67 \mathrm{a}$ \\
$\mathrm{K}_{2} \mathrm{P}_{1}$ & $6,33 \mathrm{bcd}$ & $12,50 \mathrm{abc}$ & $17,50 \mathrm{bc}$ \\
$\mathrm{K}_{2} \mathrm{P}_{2}$ & $4,08 \mathrm{a}$ & $10,25 \mathrm{ab}$ & $15,25 \mathrm{ab}$ \\
$\mathrm{K}_{3} \mathrm{P}_{0}$ & $5,08 \mathrm{abc}$ & $9,58 \mathrm{a}$ & $14,58 \mathrm{a}$ \\
$\mathrm{K}_{3} \mathrm{P}_{1}$ & $7,08 \mathrm{~d}$ & $14,67 \mathrm{c}$ & $19,67 \mathrm{c}$ \\
$\mathrm{K}_{3} \mathrm{P}_{2}$ & $5,75 \mathrm{abcd}$ & $11,67 \mathrm{ab}$ & $16,75 \mathrm{ab}$ \\
\hline $\mathrm{BNJ} 0,05$ & 1,83 & 2,79 & 2,81 \\
\hline
\end{tabular}

Keterangan : Angka yang diikuti oleh huruf yang sama pada kolom yang sama berbeda tidak nyata pada uji (BNJ) pada taraf $5 \%$.

Tabel 13 menunjukkan bahwa rata-rata jumlah daun tanaman umur 15 HST tertinggi dijumpai pada kombinasi perlakuan $\mathrm{K}_{3} \mathrm{P}_{1}$, yang secara uji BNJ 0,05 berbeda nyata dengan kombinasi perlakuan $\mathrm{K}_{0} \mathrm{P}_{0}$, $\mathrm{K}_{1} \mathrm{P}_{0}, \mathrm{~K}_{2} \mathrm{P}_{0}, \mathrm{~K}_{2} \mathrm{P}_{2}$ dan $\mathrm{K}_{3} \mathrm{P}_{0}$ namun tidak berbeda nyata dengan kombinasi perlakuan $\mathrm{K}_{0} \mathrm{P}_{1}, \mathrm{~K}_{0} \mathrm{P}_{2}$, $\mathrm{K}_{1} \mathrm{P}_{1}, \quad \mathrm{~K}_{1} \mathrm{P}_{2}, \quad \mathrm{~K}_{2} \mathrm{P}_{1}$ dan $\mathrm{K}_{3} \mathrm{P}_{2}$. Kemudian pada umur 30 dan 45 HST

\section{Jumlah Umbi Pertanaman Sampel}

Hasil pengamatan jumlah umbi pertanaman sampel bawang merah disajikan pada Lampiran 13 sedangkan hasil analisis ragam disajikan pada Lampiran 14. Hasil analisis ragam menunjukkan bahwa perlakuan kombinasi jumlah daun tertinggi dijumpai pada kombinasi perlakuan $\mathrm{K}_{3} \mathrm{P}_{1}$ yang secara uji BNJ 0,05 berbeda tidak nyata dengan kombinasi perlakuan $\mathrm{K}_{1} \mathrm{P}_{1}$ dan $\mathrm{K}_{2} \mathrm{P}_{1}$ namun berbeda nyata dengan perlakuan $\mathrm{K}_{0} \mathrm{P}_{0}, \mathrm{~K}_{0} \mathrm{P}_{1}$, $\mathrm{K}_{0} \mathrm{P}_{2}, \mathrm{~K}_{1} \mathrm{P}_{0}, \mathrm{~K}_{1} \mathrm{P}_{2}, \mathrm{~K}_{2} \mathrm{P}_{0}, \mathrm{~K}_{2} \mathrm{P}_{3}$, $\mathrm{K}_{3} \mathrm{P}_{0}$ dan $\mathrm{K}_{3} \mathrm{P}_{2}$.

jenis pupuk kandang dan ukuran pemotongan ujung umbi berpengaruh nyata pada jumlah umbi pertanaman sampel bawang merah. Rata-rata jumlah umbi pertanaman sampel bawang merah akibat perlakuan kombinasi jenis pupuk kandang dan ukuran pemotongan ujung umbi disajikan pada Tabel 14. 
Tabel 14. Rata-rata Jumlah Umbi Pertanaman Sampel Tanaman Bawang Merah akibat Pengaruh Kombinasi Jenis Pupuk Kandang dan Ukuran Pemotongan Ujung Umbi

\begin{tabular}{cc} 
Kombinasi Perlakuan & Jumlah Umbi Pertanaman Sampel \\
\hline $\mathrm{K}_{0} \mathrm{P}_{0}$ & $3,92 \mathrm{ab}$ \\
$\mathrm{K}_{0} \mathrm{P}_{1}$ & $3,67 \mathrm{ab}$ \\
$\mathrm{K}_{0} \mathrm{P}_{2}$ & $4,17 \mathrm{abc}$ \\
$\mathrm{K}_{1} \mathrm{P}_{0}$ & $3,17 \mathrm{a}$ \\
$\mathrm{K}_{1} \mathrm{P}_{1}$ & $5,58 \mathrm{c}$ \\
$\mathrm{K}_{1} \mathrm{P}_{2}$ & $3,92 \mathrm{ab}$ \\
$\mathrm{K}_{2} \mathrm{P}_{0}$ & $4,58 \mathrm{abc}$ \\
$\mathrm{K}_{2} \mathrm{P}_{1}$ & $4,92 \mathrm{bc}$ \\
$\mathrm{K}_{2} \mathrm{P}_{2}$ & $4,50 \mathrm{abc}$ \\
$\mathrm{K}_{3} \mathrm{P}_{0}$ & $4,50 \mathrm{a}$ \\
$\mathrm{K}_{3} \mathrm{P}_{1}$ & $5,67 \mathrm{c}$ \\
$\mathrm{K}_{3} \mathrm{P}_{2}$ & $4,33 \mathrm{abc}$ \\
\hline $\mathrm{BNJ} 0,05$ & 1,61 \\
\hline
\end{tabular}

Keterangan : Angka yang diikuti oleh huruf yang sama pada kolom yang sama berbeda tidak nyata pada uji (BNJ) pada taraf $5 \%$. 
Tabel 14 menunjukkan bahwa jumlah umbi pertanaman sampel bawang merah dijumpai pada kombinasi perlakuan $\mathrm{K}_{3} \mathrm{P}_{1}$, yang secara uji BNJ 0,05 berbeda nyata dengan kombinasi perlakuan $\mathrm{K}_{0} \mathrm{P}_{0}$, $\mathrm{K}_{0} \mathrm{P}_{1}, \mathrm{~K}_{1} \mathrm{P}_{0}$ dan $\mathrm{K}_{1} \mathrm{P}_{2}$ namun tidak berbeda nyata dengan kombinasi perlakuan $\mathrm{K}_{0} \mathrm{P}_{2}, \mathrm{~K}_{1} \mathrm{P}_{1}, \mathrm{~K}_{2} \mathrm{P}_{0}, \mathrm{~K}_{2} \mathrm{P}_{1}$, $\mathrm{K}_{2} \mathrm{P}_{2}, \mathrm{~K}_{3} \mathrm{P}_{0}$ dan $\mathrm{K}_{3} \mathrm{P}_{2}$. Perkembangan anakan bawang merah sangat dipengaruhi oleh pemotongan $1 / 4$ bagian dan penggunaan pupuk kandang bebek yang memiliki kanduan unsur $\mathrm{P}$ yang lebih tinggi dibandingkan pupuk kandang yan lain.

\section{KESIMPULAN DAN SARAN Kesimpulan}

1. Hasil pengamatan pemberian jenis pupuk kandang berpengaruh sangat nyata terhadap berat segar umbi per sampel, berat segar umbi per plot dan berat kering umbi per plot. Adapun tinggi tanaman (45 HST), jumlah daun $(15,30$ dan 45 HST), jumlah umbi pertanaman sampel dan berat kering umbi per sampel berpengaruh nyata. Hasil terbaik diperoleh pada perlakuan $\mathrm{K}_{3}$ (pupuk kandang bebek).

2. Hasil pengamatan perlakuan ukuran pemotongan ujung umbi berpengaruh sangat nyata terhadap tinggi tanaman dan jumlah daun (15, 30 dan 45 HST), jumlah umbi pertanaman sampel, berat segar umbi per sampel, berat segar umbi per plot, berat kering umbi per sampel dan berat kering umbi per plot. Hasil terbaik
Menurut Setiawan, $d k k .$, (2015) adanya daya regenerasi titik tumbuh meristem sel dan jumlah cadangan makanan yang tersimpan pada potongan umbi tersebut untuk perkembangan anakan dalam proses metabolisme pertumbuhannya juga reaksi hormon tumbuh yang digunakan. Selanjutnya Steffano (2017) menambahkan pemberian pupuk kotoran bebek yang memiliki hara $\mathrm{P}_{2} \mathrm{O}_{5}$ mampu meningkatkan metabolisme pertumbuhan generatif tanaman dapat tumbuh dengan baik.

diperoleh pada perlakuan $\mathrm{P}_{1}$ (pemotongan $1 / 4$ bagian).

3. Hasil pengamatan interaksi antara pengaruh jenis pupuk kandang dan ukuran pemotongan ujung umbi berpengaruh sangat nyata terhadap tinggi tanaman (45 HST). Sedangkan berpengaruh nyata pada tinggi tanaman (30 HST), jumlah daun (15, 30 dan 45 HST) dan jumlah umbi pertanaman sampel. Hasil terbaik diperoleh pada kombinasi perlakuan $\mathrm{K}_{3} \mathrm{P}_{1}$ (pengaruh jenis pupuk kandang bebek dan pemotongan $1 / 4$ bagian).

\section{Saran}

Untuk budidaya tanaman bawang merah disarankan untuk menggunakan pupuk kandang bebek dan ukuran pemotongan ujung umbi $1 / 4$ bagian dari umbi. 
DAFTAR PUSTAKA

Dinas Pertanian. 2016. Outlook Komoditas Pertanain Subsektor Hortikultura Bawang Merah. Pusat Data dan Sistem Informasi Kementerian Pertanian.

Dinas Pertanian. 2017. Statistik Pertanian 2017. Pusat Data dan Sistem Informasi Kementerian Pertanian.

Fajri, M. 2014. Pengaruh Dosis Pupuk Kandang Dan Kalium terhadap Pertumbuhan dan Hasil Tanaman Bawang Merah (Allium cepa L. Kelompok Agregatum). Skripsi. Program Studi Agroteknologi Fakultas Pertanian Universitas Teuku Umar Meulaboh, Aceh Barat.

Hartatik, W. dan L.R. Widowati, 2010. Pupuk Kandang. http://www.balittanah.litbang .deptan.go.id. Diakses tanggal 25 Mei 2019.

Hanafiah, A. K. 2011. Rancangan Percobaan (Teori dan Aplikasi). Edisi Ketiga. Raja Grafindo Persada. Jakarta.

Jumini, S., Yenny dan N. Fajri. 2010. Pengaruh Pemotongan Umbi Bibit dan Jenis Pupuk Organik terhadap Pertumbuhan dan Hasil Bawang Merah. Jurnal Floratek, 5: 164-171.

Lakitan, B., 1996. Fisiologi Pertumbuhan dan Perkembangan Tanaman. Raja Grafindo Persada. Jakarta
Lingga, Pinus dan Marsono. 2008. Petunjuk Penggunaan Pupuk. Penebar Swadaya. Jakarta.

Mulyani, S.M. dan Kartasapoetra. 1991. Pupuk dan Cara Pemupukan. Rineka Cipta. http:/ejournal.unud.ac.id/. diakses pada tanggal 25 Mei 2019.

Mujiyo dan Suryono. 2016. Pemanfaatan Kotoran Kambing pada Budidaya Tanaman Buah dalam Pot untuk Mendukung Perkembangan Pondok Pesantren. Jurnal Pemberdayaan Masyarakat. 1 (1): 5-10.

Nurhasanah, A. 2012. Pengaruh Pemotongan Umbi Bibit dan Perimbangan Pupukterhadap Pertumbuhan Hasil dan Umur Simpan Umbi Bawang (Allium Ascalonicum L). Skripsi. Pertanian Program Studi Agroekoteknologi Fakultas Pertanian Universitas Sebelas Maret Surakarta. Surakarta.

Pitojo, S. 2003. Benih Bawang Merah. Kanisius. Yogyakarta.

$\begin{array}{ccc}\text { Pranata, } & \text { Ayub } & \text { S. } \\ \text { 2010. Meningkatkan } & \text { Hasil } \\ \text { Panen dengan } & \text { Pupuk } \\ \text { Organik. Agro } & \text { Media } \\ \text { Pustaka, Jakarta. } & \end{array}$

Pradhana, A. Y. Trivana, L. 2017. Optimalisasi Waktu Pengomposan dan Kualitas Pupuk Kandang dari Kotoran Kambing dan Debu Sabut Kelapa dengan Bioaktivator 
PROMI dan Orgadec. Jurnal

Sain Veteriner. 1 : 136-144.

Raga Y. P., Haryati. Lisa M. 2012.

Respons Pertumbuhan dan Hasil Bawang Sabrang (Eleutherine americana merr.) pada Beberapa Jarak Tanam dan Berbagai Tingkat Pemotongan Umbi Bibit. Jurnal Online Agroekoteknologi, 1(1) : 159171.

Rahayu, E, dan Berlian, N. 1999. Bawang Merah. Penebar Swadaya, Jakarta.

Rahmah, A., R. Sipayung dan T. Simanungkalit. 2013. Pertumbuhan dan Hasil Bawang Merah (Allium ascalonicum L.) Pemberian Pupuk Kandang Ayam dan EM4 (Effective Microorganisms-4). Jurnal Online Agroteknologi USU. 1 (4): 2337-6597.

Rahmawati, D. 2014. Pengaruh Takaran Pupuk NPK dan Jenis Pupuk Kandang terhadap Pertumbuhan dan Hasil Tanaman Tomat (Lycopersicon esculentum Mill.) Kultivar Tymoti. Jurnal Agropanthera. 3 (1): 1-13.

Rukmana, R. 1994. Bawang Merah, Budidaya dan Pengolahan Pasca Panen. Kanisius, Yogyakarta.

Samadi, B. dan Cahyono, B., 2005. Bawang Merah Intensifikasi Usaha Tani. Kanisius, Yogyakarta.
Sartono. 2009. Budidaya Bawang Merah, Bawang Putih, dan Bawang Bombay. Intimedia. Jakarta.

Setiawan, A., Sipayung $\mathrm{R}$ dan Simanungkalit, T. 2015. Pertumbuhan dan Produksi Bawang Merah (Allium ascalonicum L.) terhadap Dosis Limbah Cair Pabrik Kelapa Sawit dan Tipe Pemotongan Umbi. Jurnal Online Agroekoteknologi, USU. 3 (1) : 340-349.

Steffano, O, D. 2017. Pengaruh Pemberian Pupuk Organik Kotoran Bebek dan Pupuk Kascing terhadap Pertumbuhan dan Hasil Produksi Tanaman Semangka (Citrullus lanatus schard). Skripsi. Program Studi Agroekoteknologi Fakultas Pertanian Universitas Muhammadiyah Sumatera Utara Medan.

Sudirja, 2007. Bawang Merah. http//www.lablink.or.id/Agro/ bawangmerah/

Alternariapartrait. html diakses tanggal 02 November 2018.

Sumadi, B. 2003. Intensifikasi Budidaya Bawang Merah. Kanisius. Yogyakarta.

Sumarni, N., dan A. Hidayat. 2005. Budidaya Bawang Merah. Panduan Teknis PTT Bawang Merah No. 3. Balai Penelitian Tanaman Sayuran. Pusat Penelitian dan Pengembangan Hortikultura. Badan Penelitian dan 
Pengembangan Pertanian. Bandung.

Suparman. 2010. Bercocok Tanam Bawang Merah. Azka Press. Jakarta.

Sutanto, R. 2002. Penerapan Pertanian Organik Pemasyarakatan dan Pengembangannya. Kanisius. Yogyakarta.

Sutanto, R. 1999. Pupuk dan Cara Pemupukan. Rineka Cipta. Jakarta.

Sutedjo, M.M, dan A.G. Kartasapoetra. 1990. Pengantar Ilmu Tanah. Bumi. Jakarta.

Syamsuddin, Salvitia D., Halimursyadah. 2016. Respon Pertumbuhan dan Hasil Bawang Merah (Allium ascalonicum) terhadap Kombinasi Dosis NPK dan Pupuk Kandang. Jurnal Ilmiah Mahasiswa Pertanian Unsyiah, 1 (1) : 217-226.

Tjitrosoepomo, G. 2010. Taksonomi Tumbuhan (Spermatophyta). UGM Press. Yogyakarta.

Wibowo, S. 2005. Budidaya Bawang Putih, Merah dan Bombay. Penebar Swadaya. Jakarta.

Widarti, B.N., Wardhini, W.K., Sarwono, E. 2015. Pengaruh rasio $\mathrm{C} / \mathrm{N}$ bahan baku pada pembuatan kompos dari kubis dan kulit pisang. Jurnal Integrasi Proses. 5 (2) : 7580.
Widjajanto, D. W. dan Sumarsono. 2005. Pertanian Organik. Badan Penerbit Universitas Diponegoro, Semarang.

Wikandari, P. R., M. H., Sholikah, Suyono. 2013. Efektivitas Kandungan Unsur Hara N Pada Pupuk Kandang Hasil Fermentasi Kotoran Ayam terhadap Pertumbuhan Tanaman Terung (Solanum melongena L). UNESA Journal of Chemistry. 2 (1) : 131136. 